\title{
The Utility of Antiserums to Subunits of TSH and LH for Immunochemical Staining of the Rat Hypophysis '
}

\author{
BURTON L. BAKER, JOHN G. PIERCE AND JAMES S. CORNELL \\ Department of Anatomy, The University of Michigan Medical School, \\ Ann Arbor, Michigan 48104 and Department of Biological Chemistry, \\ UCLA School of Medicine, Los Angeles, California 90024
}

\begin{abstract}
The objective was to assess the effectiveness of antiserums to the $\beta$-subunit of bovine TSH (thyrotropin) and $a$ - and $\beta$-subunits of LH (luteinizing hormone) for immunochemical staining of rat pituitary cells and in so doing to acquire more information about the properties of the subunits. For the following reasons it was concluded that antiserum to TSH- $\beta$ is specific for demonstration of TSH-cells. The morphology and distribution of the presumptive TSH-cells so revealed conform to the descriptions presented by other investigators who have used histological techniques. When pituitary TSH content was reduced by thyroidectomy or administration of propylthiouracil or thyroxine, the stainability of TSH-cells was reduced; it was increased with elevation of TSH content during rebound after cessation of propylthiouracil treatment. The effectiveness of anti-TSH- $\beta$ was lost after absorption with bovine TSH.

The specificity of antiserum to LH- $\beta$ for demonstration of LH-cells was indicated since the cells demonstrated with it correspond to the gonadotropic cells described by others with respect to morphology, distribution and response to gonadectomy. Antiserum to LH- $a$, the nonspecific subunit of LH, permitted staining of both TSH- and LH-cells. The individuality of TSH- and LH-cells, as revealed immunochemically with antiserums to the respective specific $\beta$-subunits, was demonstrated by double staining and by comparison of adjacent sections stained with one of the two antiserums.
\end{abstract}

Each of the hypophyseal glycoprotein hormones appears to consist of two glycopeptide chains or subunits, neither of which possesses the full biological capacity of the native molecule. After recombination of a hormone's subunits, greater potency is exhibited by the reconstituted molecule than would be expected from simple addition of the activities possessed by the two subunits. Two subunits have been isolated from luteinizing hormone (LH) of the beef (Reichert et al., '69; Liao et al., '69, '70; Hennen et al., '70; Papkoff and Gan, '70), sheep (Papkoff and Samy, '67; de la Llosa et al., '67; Ward et al., '69; Papkoff et al., '71b), rat (Ward et al., '71) and man (Reichert et al., '70; Stockell Hartree et al., '71; Rathnam and Saxena, '71); from follicle-stimulating hormone (FSH) of sheep (Papkoff and Ekblad, '70) and man (Saxena and Rathnam, '71; Reichert, '71); and from thyro- tropin (TSH) of beef (Liao and Pierce, '70) and man (Pierce et al., '71c).

One of the subunits $(a)^{2}$ is characteristic of more than one glycoprotein hormone within a species and is thus "nonspecific." On combination with an $\alpha$ subunit, the $\beta$ subunit seems to give rise to the particular biological activity of the hormone molecule and therefore may be considered "specific." Thus, the a subunits of bovine LH and TSH are similar in terms of their amino acid and carbohydrate composition, peptide maps, immunological properties, and interchangeability when combined

\footnotetext{
1 Supported in part by NIH research grants HD$03159, \mathrm{C}-2290$ and training grant GM-00364

2 Other terms that have been applied to the $\alpha$-subunit of pituitary glycoprotein hormones are CI (bovine unit of pituitary glycoprotein hormones are $\mathrm{CI}$ (bovine LH, Pierce et al., 71a), S (bovine LH, Ward et al., '66) and A (HCG, Swaminathan and Bahl, '70). Designations used by these authors for the $\beta$-subunit have been CII, A, and B, respectively. The TSH-a chain is the first of the two subunits of bovine TSH to emerge from Sephadex columns (Pierce et al., '71c) and the LH-a chain favors the aqueous phase in countercurrent distribution (Papkoff and Samy, '67).
} 
with the $\beta$-subunit in reconstitution of these hormones (Liao and Pierce, '70; Pierce et al., "71b); their amino acid sequences have recently been shown to be identical or nearly so (Liao and Pierce, '71; Pierce et al., '71a; Liu et al., '71; Papkoff et al., '71a; Maghuin-Rogister and Hennen, '71). A similar relationship exists between subunits of human LH, hCG (human chorionic gonadotropin), TSH (Pierce et al., '71b; Stockell Hartree et al., '71), and possibly with FSH (Rathman and Saxena, '71). Hybrid molecules formed by reassociation of the $\alpha$ and $\beta$ subunits of different hormones generally exhibit the biological activity characteristic of the parent hormone from which the $\beta$ subunit was obtained. Such hybridization has been effected between subunits of bovine $\mathrm{LH}$ and TSH (Liao and Pierce, '70), of bovine TSH and hCG (Pierce et al., '71b), of human LH and bovine LH (Reichert et al., '70), and of human FSH, LH, and hCG (Rathnam and Saxena, '71; Reichert, '71).

In this study antiserums to bovine TSH and $\mathrm{LH}$, and to their subunits, were employed for immunochemical staining of the rat hypophysis with the following objectives: (a) to secure more information regarding the properties of the subunits, and (b) to describe the cell types revealed by antiserums to TSH- $\beta$ and LH- $\beta$, cor- relating them with current concepts regarding the identity of TSH- and LH-cells. Verification of the specificity of these antiserums for demonstration of TSH- and LH-cells required additional experiments in which the cytology of the stained cells was correlated with experimentally altered pituitary content of TSH and LH.

\section{MATERIALS AND METHODS}

Adult Sprague-Dawley rats of both sexes were maintained in air-conditioned quarters under a daily lighting regimen of 14 hours of light and ten hours of darkness. They were fed Teklad Laboratory Chow ad libitum.

In order to acquire evidence regarding specificity of the staining procedure several experiments were carried out to alter the pituitary content of TSH and LH (table 1) and, thereby, change the cytology and staining capacity of TSH- and LH-cells. The experimental procedures used have been described (Baker and Yu, '71a). These experiments included the comparison of hypophyses from male and female rats and observation of pituitary responses to ovariectomy, orchidectomy, thyroidectomy, treatment with L-thyroxine, and administration of 6-propylthiouracil (PTU).

At termination of each experiment the rats were decapitated. The hypophyses

TABLE 1

Experiments carried out to alter the amount of TSH and LH in the hypophysis

\begin{tabular}{|c|c|c|c|c|}
\hline $\begin{array}{c}\text { Experiment } \\
\text { number }\end{array}$ & Treatment & Sex & $\begin{array}{c}\text { Number } \\
\text { of rats }\end{array}$ & $\begin{array}{c}\text { Duration } \\
\text { (days) }\end{array}$ \\
\hline 1 & $\begin{array}{l}\text { Normal rats } \\
\text { Normal rats }\end{array}$ & $\begin{array}{l}\mathrm{F} \\
\mathrm{M}\end{array}$ & - & - \\
\hline 2 & $\begin{array}{l}\text { Ovariectomy } \\
\text { Controls }\end{array}$ & $\begin{array}{l}\mathrm{F} \\
\mathrm{F}\end{array}$ & $\begin{array}{l}7 \\
7\end{array}$ & $\begin{array}{l}54 \\
54\end{array}$ \\
\hline 3 & $\begin{array}{l}\text { Orchidectomy } \\
\text { Controls }\end{array}$ & $\begin{array}{l}\text { M } \\
\text { M }\end{array}$ & $\begin{array}{l}4 \\
4\end{array}$ & $\begin{array}{l}35 \\
35\end{array}$ \\
\hline 4 & $\begin{array}{l}\text { Thyroparathyroidectomy }+100 \\
\mu \text { Ci } 131 \text { I; low iodine diet } \\
\text { Controls }\end{array}$ & $\begin{array}{l}\mathrm{F} \\
\mathrm{F}\end{array}$ & $\begin{array}{l}9 \\
5\end{array}$ & $\begin{array}{l}74 \\
74\end{array}$ \\
\hline 5 & $\begin{array}{l}\text { Propylthiouracil, } 1 \% \text { in } \\
\text { drinking fluid } \\
\text { Propylthiouracil; no treat- } \\
\text { ment last nine days } \\
\text { Controls }\end{array}$ & $\begin{array}{l}\mathbf{F} \\
\mathbf{F} \\
\mathbf{F}\end{array}$ & $\begin{array}{l}6 \\
6 \\
6\end{array}$ & $\begin{array}{l}39 \\
39 \\
39\end{array}$ \\
\hline 6 & $\begin{array}{l}\text { L-Thyroxine, } 5 \text { to } 45 \mu \mathrm{g} \text { per } \\
\text { day } \\
\text { Controls }\end{array}$ & $\begin{array}{l}F \\
F\end{array}$ & $\begin{array}{l}7 \\
7\end{array}$ & $\begin{array}{l}76 \\
76\end{array}$ \\
\hline
\end{tabular}


were fixed in Bouin's fluid, embedded in paraffin, and sectioned serially at $3 \mu$. Sections from various parts of the gland were stained immunochemically with the peroxidase-labeled antibody technique of Nakane and Pierce ('67); 3,3'-diaminobenzidine (DAB) and $\alpha$-naphthol were used as substrates for the enzyme. The antiserums to bovine TSH (anti-bTSH) ${ }^{3}$ TSH- $\beta$, LH- $\alpha$ and $\mathrm{LH}-\beta$ have been described (Liao et al., '69; Pierce et al., '71 c,d ). Control procedures for the staining reaction itself were as previously described (Baker and $\mathrm{Yu}$, '71a). For proof of specificity, the antiserums were absorbed with bovine $\mathrm{LH}$ (NIH-LH-B1) ${ }^{4}$ and bovine TSH to see if their effectiveness in the staining procedure would be lost. For absorption each antiserum was used at the maximal dilution that would still permit intense staining of pituitary cells; the absorbing hormones were employed at several concentrations.

Finally, the utility of antiserum to human TSH (anti-hTSH, provided by Dr. William D. Odell) for staining of TSH-cells was compared with that of anti-bTSH since we (Baker and $\mathrm{Yu}$, "71a,b) have recently used anti-hTSH to describe the rat TSHcell. This was done by comparing on adjacent sections the cells revealed with the two antiserums.

\section{OBSERVATIONS}

\section{Staining with antiserums to bovine TSH- $\beta$ and TSH}

Anti-TSH- $\beta$. Anti-TSH- $\beta$ permitted immunochemical staining of TSH-cells. They were typically polygonal (figs. 8, 21) and their variable size bore a direct relationship to staining intensity. TSH-cells were most numerous in the centromedial and ventral regions of the lateral lobes of the pars distalis (fig. 2), this concentration of cells extending into the caudalmost part of the gland (fig. 3). TSH-cells were less numerous laterally and dorsally; they were almost absent from a narrow zone alongside the pars intermedia and from the dorsocephalic region where many gonadotropic cells are located (fig. 1).

Anti-TSH- $\beta$ possessed a high antibody titer. Intense staining of TSH-cells occurred at a dilution of $1 / 500$ with some decline in effectiveness being noted at a dilution of $1 / 600$. Anti-TSH- $\beta$ revealed the same population of cells whether employed at full strength or at a dilution of $1 / 500$.

Anti-bTSH. Anti-bTSH also permitted the staining of TSH-cells but when used at full strength or at low dilution gonadotropic cells were demonstrated also (fig. 7). The staining of gonadotropic cells was weak at a dilution of $1 / 25$ and had disappeared at $1 / 50$ (fig. 8). Anti-bTSH remained maximally effective at a dilution of 1/100 and although somewhat less intense, strong staining was obtained at 1/500. At dilutions of anti-bTSH sufficient to eliminate the staining of gonadotropic cells, the cells revealed with it and antiTSH- $\beta$ were identical as shown by comparison of adjacent sections, each of which was stained with one of the two antiserums.

Cytology of TSH-cells after alteration in pituitary hormone content. The following description of experimentally induced alterations in TSH-cells is based on staining with anti-TSH- $\beta$. Ovariectomy is reported to reduce the concentration and total amount of TSH in the hypophysis (D'Angelo, '66). However, TSH-cells stained more intensely after ovariectomy and a change in number and size of the cells could not be demonstrated. We found that TSH-cells lost much of their staining capacity when pituitary thyrotropic content was reduced by thyroidectomy (Contopoulos et al., '58), PTU administration (fig. 10) (D'Angelo, '61) or treatment with thyroxine (D'Angelo, '58). Distinctive was the capacity of anti-TSH- $\beta$ to permit significant staining of the cytoplasm and rather intense staining of the Golgi apparatus in many of the enlarged TSH-cells from hypothyroid rats; a similar result was obtained with anti-TSH- $\alpha$ (figs. 16, 17). A few TSH-cells remained unaffected by either thyroid deficiency or injection of thyroxine. During the rebound period after cessation of PTU treatment, pituitary TSH content rises to a level several times that of the normal rat (D'Angelo, '61). At the

\footnotetext{
3 In abbreviations for hormones " $b$ " will be used to designate a bovine origin, "o" for ovine, and "h" for human. Antiserums will be indicated by addition of the prefix "anti" to the name of the hormone.

4 We express our appreciation to the following sources for the materials indicated: A. R. Midgley, Jr., antiserums to ovine LH (NIH-LH-S12) and human chorionic gon adotropin; and The Endocrinology Study Section of NIH for bovine LH (NIH-LH-BI).
} 
end of this period the staining intensity of TSH-cells and thyroidectomy cells that results from use of anti-TSH- $\beta$ was increased over that in glands from rats continuing to receive PTU (figs. 10, 11).

\section{Comparison of the properties of antiserums to bTSH and TSH- $\beta$ with anti-hTSH}

Observation of the cells delineated in adjacent sections, one of which was stained with either anti-bTSH or antiTSH- $\beta$ and the other with anti-hTSH revealed several important similarities and some differences. First, all T'SH-cells demonstrated with anti-hTSH were also stained with anti-bTSH and anti-TSH- $\beta$. However, at least with anti-TSH- $\beta$ more TSH-cells were revealed including numerous small, lightly stained polygonal cells that appeared to contain a low concentration of thyrotropin. Similarly the cytoplasm of TSH-cells and thyroidectomy cells in the hypothyroid rat, although depleted of hormone, stained more intensely with antiTSH- $\beta$ than with anti-hTSH. On the other hand, in rats during rebound after cessation of PTU treatment when the pituitary TSH content is several times higher than normal, anti-hTSH stained the gland more intensely than in the nontreated controls (Baker and Yu, '71a,b) while anti-TSH- $\beta$ failed to do so (figs. 9,10 ) unless used at low $(<1 / 25)$ dilution.

\section{Staining with antiserums to subunits of bovine $L H$}

Anti-LH- $\beta$. LH-cells were distributed throughout the pars distalis with the number of cells per unit area varying considerably in different regions. $\mathrm{LH}$-cells ${ }^{5}$ were most numerous in the dorsocephalic "sex zone," in a caudal extension of this aggregation along the pars intermedia, ventrally in clusters around the larger blood vessels, and in ventrolateral foci under the lateral tips of the pars distalis (fig. 4). Their distribution extended into the caudal region (fig. 6). LH-cells varied in size and form in different areas. In the dorsocephalic region and when scattered generally throughout the gland, they were usually ovoid; they reached their greatest size dorsocephalically. Ventrally and ventrolater- ally LH-cells were smaller and tended to be more polyhedral.

Intense staining of $\mathrm{LH}$-cells occurred when anti-LH- $\beta$ was used up to a dilution of $1 / 300 ; a$ decline in effectiveness occurred at 1/400. Observation of cells in adjacent sections, one of which was stained with anti-LH- $\beta$ and the other with either anti-hCG or anti-oLH, revealed that identical cells were delineated with all three antiserums (figs. 18-20).

Immunochemical staining with antiserums to the $\beta$-subunits of TSH and LH revealed distinctly different cell types. When TSH- and LH-cells were demonstrated in a single section by double immunochemical staining, using anti-TSH- $\beta$ and anti-LH- $\beta$ and DAB and $\alpha$-naphthol (followed by staining with pyronin) as peroxidase substrates, respectively, the TSH-cells appeared gold and LH-cells lavender with no cells possessing both colors (fig. 21). Also, comparison of adjacent sections stained with either anti-TSH- $\beta$ or anti-LH- $\beta$ showed that different cells were brought out by the two antiserums (figs. $22,23)$.

Cytology of LH-cells after alteration in pituitary $\mathrm{LH}$-content. The following observations were made on hypophyses stained immunochemically with anti-LH- $\beta$. Ovariectomy and orchidectomy increase the pituitary content of LH (Parlow, '64a,b). Fifty-four days after ovariectomy LH-cells were enlarged and many of them contained large vacuoles. Although LHcells stained intensely in the nonoperated controls (fig. 14), after ovariectomy their immunochemical reactivity with anti-LH- $\beta$ was exceedingly weak (fig. 15). Thirty-five days after orchidectomy the enlarged $\mathbf{L H}$ cells also stained less intensely than in the nonoperated controls. A similar decline in staining capacity of LH-cells after prior castration of the rats was observed with anti-oLH and anti-hCG.

Experimental alteration in the level of circulating thyroid hormone caused little change in LH-cells. In hypothyroidism, when the pituitary content of LH is said to be elevated (Contopoulos et al., '58) a reduction in size and staining capacity of

\footnotetext{
5 Although in this laboratory the FSH-cell has not yet been differentiated from the LH-cell, the cell revealed with anti-LH- $\beta$ will be designated the LH-cell in this paper for reasons enumerated in the text.
} 
LH-cells occurred in some thyroid-deficient animals but not in others. During the rebound period after termination of PTU treatment, LH-cells were mildly enlarged in only some rats. Administration of thyroxine elicited a small and inconsistent hypertrophy of LH-cells.

Anti-LH- $\alpha$. Following application of anti-LH- $\alpha$ (fig. 12) far more cells were stained immunochemically than after antiLH- $\beta$ (fig. 14). Many were typical LH-cells. Most or all of the additional cells were TSH-cells as shown by their polygonal shape, large size, dominant distribution in the centromedial region of the lateral lobes, by the presence of both gold and lavender in their cytoplasm after double immunochemical staining with anti-TSH- $\beta$ and anti-LH- $\alpha$, their disappearance in rats treated with thyroxine, and their enlargement, vacuolation and reduction in staining capacity in rats made hypothyroid.

Following ovariectomy, the cytoplasm of the enlarged LH-cells and castration cells stained intensely with anti-LH- $\alpha$ (fig. 13) in contrast to their minimal response to the application of anti-LH- $\beta$ (fig. 15).

\section{The influence of absorption with various} hormones on the utility of the antiserums for immunochemical staining

Specificity of the antiserums to bTSH, TSH- $\beta$, LH- $\alpha$, and LH- $\beta$ was studied by absorption with several hormones. The staining effectiveness of anti-bTSH and antiTSH- $\beta$ was eliminated by prior absorption with bTSH while absorption with bLH resulted in only a moderate decline (table 2 ). After absorption of anti-LH- $\alpha$ and antiLH- $\beta$ with bLH, the effectiveness of antiLH- $\alpha$ was eliminated and that of anti-LH- $\beta$ almost completely so. Absorption with
bTSH negated the usefulness of anti-LH- $\alpha$ but had a minimal effect on anti-LH- $\beta$. Thus, cross-reactivity was obtained between bTSH and antiserum to the LH- $\alpha$ subunit. Our observations of cross-reactivity are similar to those reported by Pierce et al. ('71c) with double-diffusion and immunoelectrophoresis techniques. Absorption with the non-carbohydrate-containing synthetic polypeptide $\beta^{1-24}-\mathrm{ACTH}$ (corticotropin) did not alter the antiserums.

\section{DISCUSSION}

Specificity of anti-TSH- $\beta$. Much evidence indicates that anti-TSH- $\beta$ is highly specific for use in immunochemical staining of the TSH-cell in the rat. The polyhedral shape and large size of the stained cells fit the descriptions of TSH-cells as reported previously by investigators who used histochemical (Purves and Griesbach, '51b; Halmi, '52) and immunochemical (Nakane, '70; Baker and Yu, '71a,b) staining procedures. The distribution of TSHcells in the pituitary gland of the rat as observed after histochemical staining (Purves and Griesbach, '51a) corresponds with that revealed previously by immunochemical staining with anti-hTSH (Baker and $\mathrm{Yu}$, '71a) and in this study with bovine anti-TSH- $\beta$. In experimental situations accompanied by reduction in pituitary TSH content, as in hypothyroidism (D'Angelo, '63) and after treatment with thyroxine (Mess, '58; D'Angelo, '61), the staining capacity of TSH-cells with antiTSH $-\beta$ is greatly reduced or lost. On the contrary, enhancement of pituitary content during the rebound period after cessation of treatment with PTU (D'Angelo, '61) is accompanied by an increase in the staining intensity of TSH-cells. Prior absorption of anti-TSH- $\beta$ with bTSH pre-

TABLE 2

The effect of pre-absorption of antiserums with hormones on their usefulness for immunochemical staining of TSH-and LH-cells

\begin{tabular}{|c|c|c|c|c|}
\hline \multirow{2}{*}{$\begin{array}{l}\text { Hormone } \\
\text { absorbant }\end{array}$} & \multicolumn{4}{|c|}{$\begin{array}{l}\text { Intensity of staining obtained } \\
\text { after absorption of antiserums }\end{array}$} \\
\hline & Anti-bTSH & Anti-TSH- $\beta$ & Anti-LH- $a$ & Anti-LH- $\beta$ \\
\hline Bovine LH & ++1 & $+1+$ & 0 & \pm \\
\hline Bovine TSH & 0 & 0 & 0 & $+t+$ \\
\hline$\beta^{1-24}-\mathrm{ACTH}$ & $++t+$ & $++t+$ & $+1+1$ & $+t+$ \\
\hline
\end{tabular}

1 The intensity of staining in TSH- and LH-cells is rated visually from 0 to ++++ . 
vented staining of TSH-cells. Finally, in sections stained immunochemically for both LH- and TSH-cells, utilizing antiTSH- $\beta$ and anti-LH- $\beta$ distinctly different cell types were brought out. Of special significance is the fact that antiserum to the specific $\beta$-subunit of the TSH molecule can reveal the same cells that would appear if antiserum to the entire molecule had been used.

When anti-hTSH (Baker and Yu, '71a,b) and anti-bTSH were used in immunochemical staining at minimal dilution, gonadotropic ( $\mathrm{LH}-$ ) cells were stained in addition to TSH-cells. A possible explanation for this response is the presence of antibodies against contaminating LH molecules in the original TSH preparation used for immunization. However, with respect to anti-bTSH this seems unlikely since by rechromatography on DEAE-cellulose and/or by neutralization with antiserum to bovine LH, LH activity of the TSH preparation was reduced to less than $0.02 \mathrm{LH}$ units per $\mathrm{mg}$ relative to NIHLH-Sl. Furthermore, no cross-reactivity between bTSH and bLH was observed with immunodiffusion and immunoelectrophoretic methods (Shome et al., "68).

Since, as summarized previously, the present limited knowledge concerning the properties of the subunits of pituitary glycoprotein hormones indicates that the a-subunit may be nonspecific with respect to type of hormone and species, a second possible explanation for the staining of LH-cells with anti-TSH may be suggested. If antigenic sites characteristic of the a-subunit of TSH are still free in the native TSH molecule, some antibodies might appear in the antiserum that could react with intracellular LH. Militating against this possibility is the failure of anti-bTSH to cross-react with $\mathrm{LH}-\alpha$ in immunoelectrophoresis, even though TSH recognizes binding sites in the antiserum to LH $\alpha$ (Liao et al., '69; Pierce et al., '71c, table VI). Another possibility is that fixation had altered the immunologic properties of LH contained within the pituitary cells being stained. Nevertheless, the presence of a low titer of antibodies to $\mathrm{LH}$ in antiserums to TSH need not interfere with use of these antiserums for immunochemical staining of TSH-cells since this capac- ity was eliminated either by dilution (at 1/50 for anti-bTSH and at 1/300 for antihTSH) or by absorption with hCG.

Anti-TSH- $\beta$ may possess greater sensitivity for the immunochemical demonstration of TSH-cell in the normal rat than does anti-hTSH (Baker and Yu, '71a,b). When anti-hTSH was used at a dilution $(1 / 300)$ adequate to eliminate the staining of LH-cells, and anti-TSH- $\beta$ was employed at its maximal fully effective dilution, the TSH-cells revealed with antihTSH were all stained with anti-TSH- $\beta$ but, in addition, the latter antiserum brought out more cells, many of which were lightly stained and apparently contained a low level of TSH. That they are TSH-cells is indicated by their immunochemically demonstrated morphology, distribution in the gland and cytological response to experimentally altered hormone content in the hypophysis; on the basis of these criteria the lightly stained cells are not growth hormone, prolactin (Baker et al., '69) or corticotropic (Baker et al., '70) cells, and according to our preliminary observations, not FSH-cells. Finally, the cytoplasm of TSH-cells when depleted of hormone by administration of PTU or by thyroidectomy, stained more intensely with antiTSH- $\beta$ than with anti-hTSH.

Specificity of anti-LH- $\beta$. The characteristics of LH-cells stained immunochemically with anti-LH- $\beta$ correspond with those of gonadotropic cells as defined by other investigators who used histological, histochemical and immunohistological techniques (Purves and Griesbach, '51a; Purves, '61; Monroe and Midgley, '69; Baker and Yu, '70). With minor exceptions these features include the distinctive ovoid form and distribution of gonadotropic cells in the gland, as well as their enlargement and vacuolation following gonadectomy. Although LH- $\beta$ is only a part of the LH molecule, antiserum to it permits staining of the same cells as anti-oLH and anti-hCG. In this study the individuality of TSH- and LH-cells was demonstrated clearly in several ways. However, the relationship of the cells that secrete FSH to TSH- and L.H-cells is not fully clarified (Baker, in press), although from immunochemical observations Nakane ('70) con- 
cluded that some of the LH-cells also secrete FSH.

Nonspecificity of anti-LH- $\alpha$. Anti-LH- $\alpha$ permitted the staining of both $\mathrm{LH}$ - and TSH-cells. This result is to be expected because Liao et al. ('69) observed immunologic cross-reactivity between anti-LH- $\alpha$ and bovine TSH and noted a close chemical similarity between LH- $\alpha$ and TSH except for molecular size. Thus, it appears probable that the presence of the nonspecific a-subunit in TSH provides common recognition sites in the two molecules.

Unexpected staining with anti-LH- $\beta$ and anti-TSH- $\beta$. In our experiments, unexpected staining reactions to the $\beta$-subunits of both TSH and LH were observed in two experimental situations. The hypophysis of the ovariectomized rat contains an elevated LH content (Parlow, '64b) along with enlarged gonadotropic cells, some of which are vacuolated. Although these gonadotropic cells stain intensely with anti-LH- $\alpha$, the reaction is exceedingly weak with anti-LH- $\beta$. However, this does not appear to have resulted from a peculiarity of the antibodies to LH- $\beta$ since weak staining also occurred when anti-oLH and anti-hCG were used.

A second unusual situation pertains to the TSH-cells. Seven to twelve days after cessation of PTU treatment, the TSH content of the pituitary gland is four to eight times higher than in the normal rat (D'Angelo, '61). With anti-hTSH (Baker and $\left.\mathrm{Yu},{ }^{\prime} 71 \mathrm{a}\right)$ and anti-bTSH the overall intensity of immunochemical staining in TSH-cells of hypophyses from rats in rebound was greater than in non-PTUtreated rats. On the other hand when antiTSH- $\beta$ was used at a high dilution that would still give maximal staining of TSHcells, the TSH-cells of rats in rebound stained more intensely than the hormonedepleted cells of rats continuing to receive PTU, but failed to become darker than TSH-cells of control rats not treated with PTU. The explanation for these observations is not evident; however, under conditions of elevated hormone storage, some receptor sites on the hormone molecule may not be free to receive the antibody to the $\beta$-subunit.

In conclusion, antiserums to the $\beta$-subunits of bTSH and bLH represent a useful new tool for the immunochemical study of pituitary cytology because of their specificity and high potency. However, under some experimental situations their apparent incapacity to react with intracellular hormone remains unexplained.

\section{LITERATURE CITED}

Baker, B. L. The functional cytology of the hypophyseal pars distalis and pars intermedia. In: The Pituitary Gland and Its Control-Adenohypophysis. Section on Endocrinology, Handbook of Physiology. E. Knobil, ed., in press.

Baker, B. L., A. R. Midgley, Jr., B. E. Gersten and Y. Y. Yu 1969 Differentiation of growth hormone- and prolactin-containing acidophils with peroxidase-labeled antibody. Anat. Rec., 164: 163-172.

Baker, B. L., S. Pek, A. R. Midgley, Jr, and B. E. Gersten 1970 Identification of the corticotropin cell in rat hypophyses with peroxidaselabeled antibody. Anat. Rec., 166: 557-568.

Baker, B. L., and Y. Y. Yu 1970 The influence of norethynodrel on the hypophysis. Proc. Soc. Exp. Biol. Med., 134: 107-112.

- 1971a The thyrotropic cell of the rat hypophysis as studied with peroxidase-labeled antibody. Am. J. Anat, 131: 55-72.

- 1971b Hypophyseal changes induced by thyroid deficiency and thyroxine administration as revealed by immunochemical stain. ing. Endocrinology, 89: 996-1004.

Contopoulos, A. N., M. E. Simpson and A. A. Koneff 1958 Pituitary function in the thyroidectomized rat. Endocrinology, 63: 642-653.

D'Angelo, S. A. 1958 Role of the hypothalamus in pituitary-thyroid interplay. J. Endocr,, 17: 286-299.

1961 TSH rebound phenomenon in the rat adenohypophysis. Endocrinology, 69: 834843.

1963 Histophysiology of TSH secretion in the rodent. In: Cytologie de L'Adénohypophyse. J. Benoit and C. Da Lage, eds. Editions du Centre National de la Recherche Scientifique, Paris, pp. 149-162.

I966 A comparative study of TSH and FSH secretion in rat and guinea pig: effects of gonadectomy and goitrogens. Endocrinology, 78: 1230-1237.

de la Llosa, P., C. Courte and M. Jutisz 1967 On the mechanism of reversible inactivation of Iuteinizing hormone by urea. Biochem. Biophys. Res. Commun., 26: 411-416.

Halmi, N. S. 1952 Two types of basophils in the rat pituitary: "thyrotrophs" and "gonadotrophs" vs. beta and delta cells. Endocrinology, 50: 140-142.

Hennen, G., G. Maghuin-Rogister and G. Mamoir 1970 The subunits of bovine thyrotropin. Their isolation and comparison with the subunits of Iuteinizing hormone. FEBS Letters, 9: 20-26.

Liao, T.-H., G. Hennen, S. M. Howard, B. Shome and J. G. Pierce 1969 Bovine thyrotropin. 
Countercurrent distribution and a comparison with the isolated subunits of luteinizing hormone. J. Biol. Chem., 244: 6458-6467.

Liao, T.-H., and J. G. Pierce 1970 The presence of a common type of subunit in bovine thyroidstimulating and luteinizing hormones. J. Biol. Chem., 245: 3275-3281.

1971 The primary structure of bovine thyrotropin. II. 'The amino acid sequences of the reduced, S-carboxymethyl $a$ and $\beta$ chains. J. Biol. Chern., 246: 850-865.

Liu, W.-K., H. S. Nahm, C. M. Sweeney, N. Baker, W. M. Lamkin and D. N. Ward 1971 The amino acid sequence of the S-aminoethylated ovine luteinizing hormone S-subunit (LH-a). Res. Commun. Chem. Path. Pharmacol., 2: $168-176$.

Maghuin-Rogister, G., and G. Hennen 1971 Structural variability in bovine luteinizing hormone. In: Structure-Activity Relationships of Protein and Polypeptide Hormones. M. Margoulies and F. C. Greenwood, eds. International Congress Series 241, Excerpta Medica, Amsterdam, Part I, pp. 91-98.

Mess, B. 1958 Veränderungen des Gehaltes der Hypophyse an thyreotropem Hormon nach Thyreoidektomie und gleichzeitiger Läsion der Nuclei habenulae. Endokrinologie, 35: 296-301.

Monroe, S. E., and A. R. Midgley, Jr. 1969 Immunofluorescent localization of rat luteinizing hormone. Proc. Soc. Exp. Biol. Med., 130: 151-156.

Nakane, P. K. 1970 Classifications of anterior pituitary cell types with immunoenzyme histochemistry. J. Histochem. Cytochem., 18: 9-20.

Nakane, P. K., and G. B. Pierce, Jr. 1967 Enzyme-labeled antibodies for the light and electron microscopic localization of tissue antigens. J. Cell Biol., 33: 307-318.

Papkoff, H., and M. Ekblad 1970 Ovine follicle stimulating hormone: preparation and characterization of its subunits. Biochem. Biophys. Res. Commun., 40: 614-621.

Papkoff, H., and J. Gan 1970 Bovine interstitial cell-stimulating hormone: purification and properties. Arch. Biochem. Biophys., 136: $522-528$.

Papkoff, H., M. R. Sairam and C. H. Li 1971a Amino acid sequence of the subunits of ovine pituitary interstitial cell-stimulating hormone. J. Am. Chem. Soc., 93: 1531-1532.

Papkoff, H., and T. S. A. Samy 1967 Isolation and partial characterization of the polypeptide chains of ovine interstitial cell-stimulating hormone. Biochim. Biophys. Acta, 147: 175-177.

Papkoff, H., J. Solis-Wallckermann, M. Martin and C. H. Li $1971 \mathrm{~b}$ Immunochemical properties of ovine interstitial cell-stimulating hormone subunits. Arch. Biochem. Biophys, 143: 226-231.

Parlow, A. F. 1964a Importance of differential, quantitative bio-assays for pituitary gonadotrophins in the rat. Endocrinology, 74: 138-141. $1964 \mathrm{~b}$ Comparison of pituitary and serum gonadotrophins of the rat. Endocrinology, 74: 489-492.

Pierce, J. G., T.-H. Liao, R. B. Carlsen and T. Reimo 1971a Comparisons between the a chain of bovine thyrotropin and the CI chain of luteinizing hormone. Compositions of tryptic peptides, cyanogen bromide fragments, and carbohydrate moieties. J. Biol. Chem., 246: 866-872.

Pierce, J. G., O. P. Bahl, J. S. Cornell and N. Swaminathan $1971 \mathrm{~b}$ Biologically active hormones prepared by recombination of the a chain of human chorionic gonadotrop:n and the hormone-specific chain of bovine thyrotropin or of bovine luteinizing hormone. J. Biol. Chem., 246: 2321-2324.

Pierce, J. G., T.-H. Liao, S. M. Howard, B. Shome and J. S. Cornell 1971c Studies on the structure of thyrotropin: its relationship to luteinizing hormone. Rec. Progr. Horm. Res., 27: 165-212.

Pierce, J. G., T.-H. Liao, J. S. Cornell and R. B. Carlsen 1971d Thyrotropin and its subunits. In: Structure-Activity Relationships of Protein and Polypeptide Hormones. M. Margoulies and F. C. Greenwood, eds. International Congress Series 241, Excerpta Medica, Amsterdam, Part I.

Purves, H. D. 1961 Morphology of the hypophysis related to its function. In: Sex and Internal Secretions. Vol. 1 W. C. Young, ed. Third edition. The Williams \& Wilkins Co., Baltimore, pp. 161-239.

Purves, H. D., and W. E. Griesbach 1951a The site of thyrotrophin and gonadotrophin production in the rat pituitary studied by McManusHotchkiss staining for glycoprotein. Endocrinology, 49: 244-264.

1951b The significance of the Gomori staining of the basophils of the rat pituitary. Endocrinology, 49: 652-662.

Rathnam, P., and B. B. Saxena 1971 Subunits of luteinizing hormone from human pituitary glands. J. Biol. Chem., 246: 7087-7094.

Reichert, L. E., Jr. 1961 Differential effect of hydrogen peroxide upon the biological activity of thyroid stimulating hormone and luteinizing hormone. Endocrinology, 69: 398-400.

1971 Biological evidence for the subunit structure of human follicle-stimulating hormone. Endocrinology, 89: 925-928.

Reichert, L. E., Jr., A. R. Midgley, Jr., G. D. Niswender and D. N. Ward 1970 Formation of a hybrid molecule from subunits of human and bovine luteinizing hormone. Endocrinology, 87: 534-541.

Reichert, L. E., Jr., M. A. Rasco, D. N. Ward, G. D. Niswender and A. R. Midgley, Jr. 1969 Isolation and properties of subunits of bovine pituitary luteinizing hormone. J. Biol. Chem., 244: 5110-5117.

Saxena, B. B., and P. Rathnam 1971 Dissociation phenomenon and subunit nature of folliclestimulating hormone from human pituitary glands. J. Biol. Chem., 246: 3549-3554.

Shome, B., A. F. Parlow, V. D. Ramirez, H. Elrick and J. G. Pierce 1968 Human and porcine thyrotropins: a comparison of electrophoretic and immunological properties with the bovine hormone. Arch. Biochem. Biophys., 126: $444-455$. 
Stockell Hartree, A., M. Thomas, M. Braikevitch, E. T. Bell, D. W. Christie, G. V. Spaull, R. Taylor and J. G. Pierce 1971 Preparation and properties of subunits of human luteinizing hormone. J. Endocr., 51: 169-180.

Swaminathan, N., and O. P. Bahl 1970 Dissociation and recombination of the subunits of human chorionic gonadotropin. Biochem. Biophys. Res. Commun., 40: 422-427.

Ward, D. N., M. Fujino and W. M. Lamkin 1966 Evidence for two carbohydrate moieties in ovine luteinizing hormone (LH). Fed. Proc., 25: 348 (abstract).
Ward, D. N., L. E. Reichert, Jr., B. A. Fitak, H. S. Nahm, C. M. Sweeney and J. D. Neill 1971 Isolation and properties of subunits of rat pituitary luteinizing hormone. Biochemistry, 10: 1796-1802.

Ward, D. N., C. M. Sweeney, G. N. Holcomb, W. M. Lamkin and M. Fujino 1969 Recent studies on the structure of ovine luteinizing hormone. In: Progress in Endocrinology, Proceedings of the Third International Congress. Int. Cong. Series No. 184, Excerpta Medica Foundation, Amsterdam, pp. 385-393. 


\author{
Abbreviations \\ $D$, pars distalis \\ I, pars intermedia \\ $\mathrm{N}$, pars nervosa
}

PLATE 1

EXPLANATION OF FIGURES

All photographs on this plate are of transverse sections through the hypophysis of female rats and represent one-half of the gland. The dorsal surface is on the left and ventral surface on the right. Figures 1-3 were stained immunochemically with anti-TSH- $\beta$ and figures 4-6 with antiLH $-\beta$. $\times 38$.

1 Cephalic section. TSH-cells are distributed sparsely in the pars distalis.

2 Middle section. TSH-cells are most numerous in the centromedian area of the lateral lobe of the pars distalis.

3 Caudal section. TSH-cells continue into the ventrocaudal region.

4 Cephalic section. LH-cells appear throughout the pars distalis but in this section are most numerous dorsally, along the ventral surface, and adjacent to the ventrolateral groove in the gland (arrow).

5 Middle section. LH-cells are distributed uniformly.

6 Caudal section. LH-cell are most numerous ventrally and laterally. 

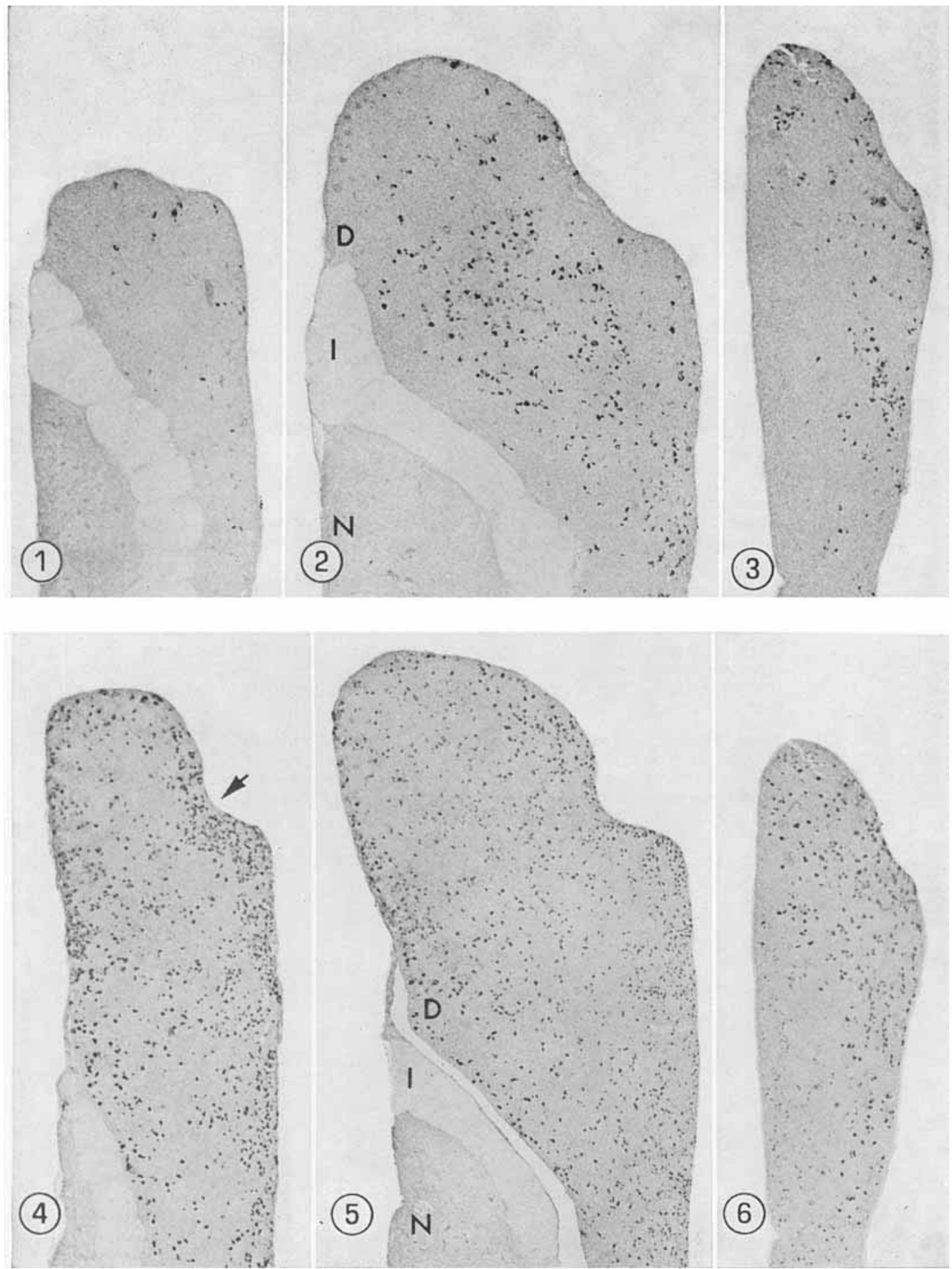
PLATE 2

EXPLANATION OF FIGURES

Figures 7 and 8 illustrate sections of the female hypophysis stained with anti-TSH. $\times 250$. Figures $9-11$ are stained with anti-TSH- $\beta . \times 250$.

7 Section stained with undiluted antiserum to bTSH. TSH-cells (black, T) and LH-cells ( gray, L) are stained.

8 A section near that illustrated in figure 7 , stained with anti-bTSH diluted 1/50. Only TSH-cells are stained.

9 Hypophysis of a control female rat stained with anti-TSH- $\beta$. TSH-cells are shown.

10 Hypophysis of a female rat fed propylthiouracil (PTU) for 38 days. Most TSH-cells (T) are hypertrophied, and poorly but distinctly stained. Some (arrows) are vacuolated and would be termed thyroidectomy cells. A few small dark TSH-cells did not respond to the thyroid deficiency.

11 Hypophysis of a female rat that received PTU for 30 days but not for the last eight days of life. During the latter rebound period the TSH-cells developed an increased staining capacity which, when demonstrated with anti-TSH- $\beta$ at dilutions of $1 / 100$ or greater, did not surpass that of the controls (fig. 9). 
STAINING WITH ANTISERUMS TO SUBUNITS OF TSH AND LH

PLATE 2

B. L. Baker, J. G. Pierce and J. S. Cornell

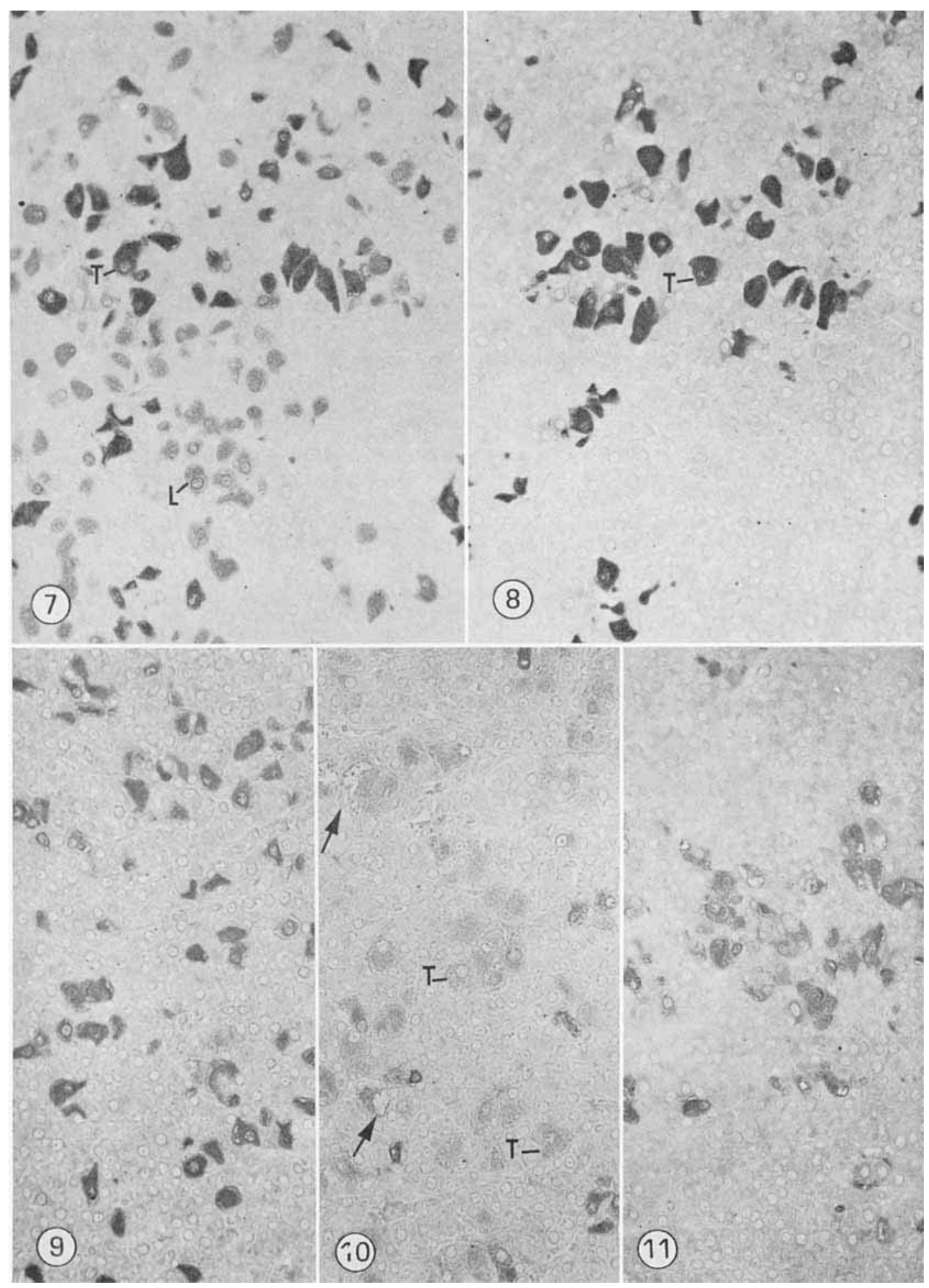


PLATE 3

EXPLANATION OF FIGURES

12 Hypophysis of a control female rat stained with anti-LH-a. A mixture of TSH- and LH-cells are stained. $\times 250$.

13 Hypophysis of a female rat 54 days after ovariectomy stained with anti-LH- $a$. LH-cells are enlarged, intensely stained and some are vacuolated. $\times 250$.

14 Hypophysis of control female rat stained with anti-LH- $\beta$. Only LHcells are stained and, hence, the number of cells is less than appear when anti-LH- $\alpha$ (fig. 12 ) is used. $\times 250$.

15 Hypophysis of a female rat 54 days after ovariectomy, stained with anti-LH- $\beta$. LH-cells (L) are enlarged and many are vacuolated, but as compared with anti-LH- $\alpha$ (fig. 13) they stain poorly with anti-LH- $\beta$ $\times 250$.

16 Hypophysis of female rat stained with anti-LH- $a$ which reveals both LH- and TSH-cells. Probable TSH- (T) and LH-cells (L) are indicated. $\times 1000$.

17 Hypophysis of a female rat 74 days after thyroidectomy. Vacuolated "thyroidectomy" cells (Tx) are poorly stained. Hypertrophied TSHcells (T) possess an enlarged and well-stained Golgi area (G). Probable L.H-cells $(\mathbb{L})$ are unaffected by the thyroid deficiency. $\times 1000$. 
STAINING WITH ANTISERUMS TO SUBUNITS OF TSH AND LH

B. L. Baker, J. G. Pierce and J. S. Cornell

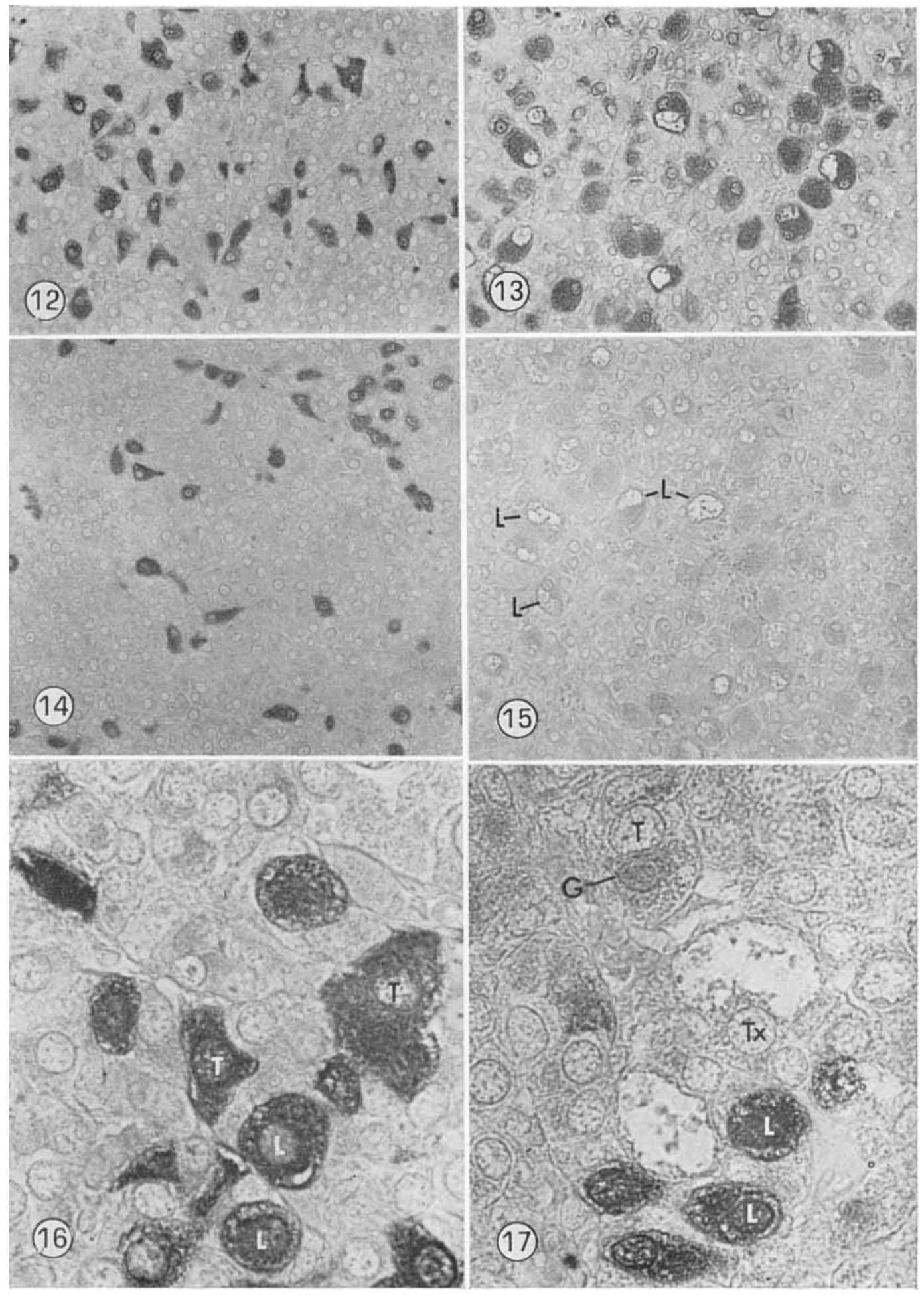


PLATE 4

EXPLANATION OF FIGURES

Figures 18-20 jllustrate successive sections from a hypophysis of a female rat stained, respectively, with anti-LH- $\beta$, anti-oLH and anti-hCG to show that the same cell is revealed by each of the antiserums. A number identifies the same cell in each of the three sections. $\times 400$.

18 Section stained with anti-LH $\beta$.

19 Section stained with anti-oLH.

20 Section stained with anti-hCG.

21 Hypophysis of a female rat doubly stained for TSH- (T) and LH-cells (L) with anti-TSH- $\beta$ and anti-LH- $\beta$ using DAB and $\alpha$-naphthol (followed with pyronin), respectively, as substrates. TSH-cells appear gold and LH-cells lavender. $\times 1000$.

Figures 22 and 23 are successive hypophyseal sections one of which was stained with anti-TSH- $\beta$ and the other with anti-LH- $\beta$ to show the individuality of TSH- and LH-cells as revealed with antiserums to the $\beta$-subunits. The identity of cells in the two photographs is indicated by numbers. $\times 600$.

22 Section stained with anti-TSH- $\beta$. Most of the TSH-cells are polygonal. In this section LH-cells shown in figure 23 are not stained.

23 Section stained with anti-LH- $\beta$. The LH-cells are generally ovoid and the TSH-cells of figure 22 are unstained. 
B. L. Baker, J. G. Pierce and J. S. Cornell

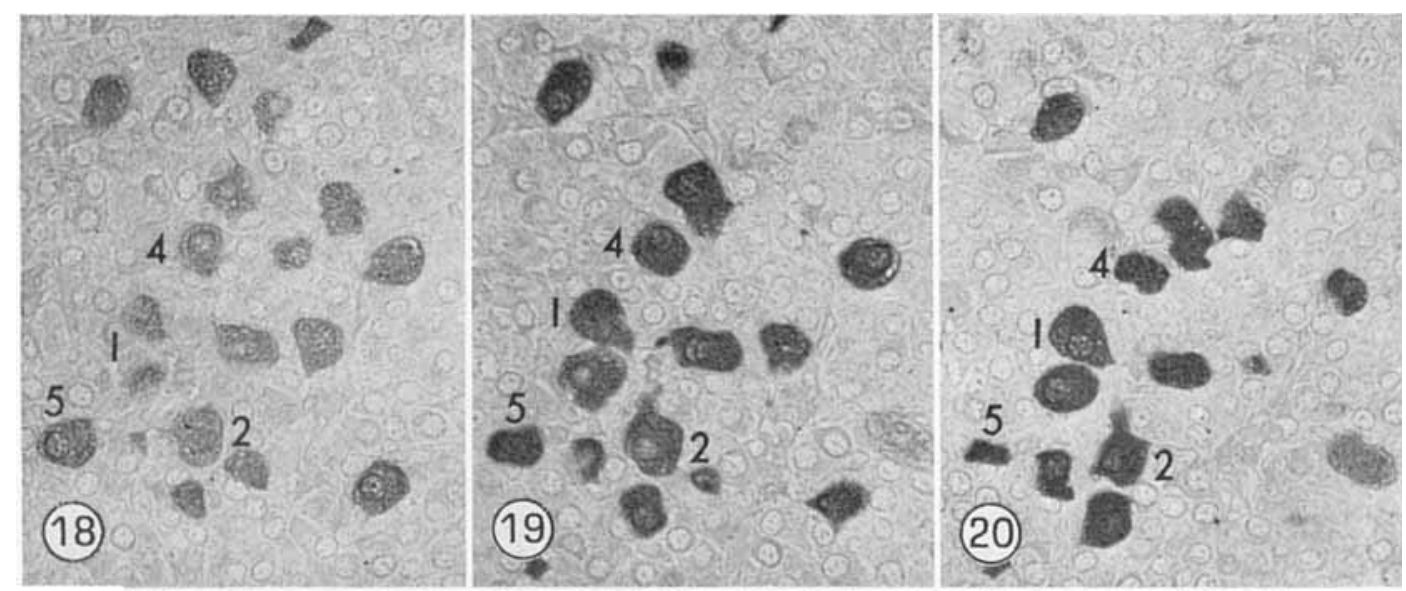

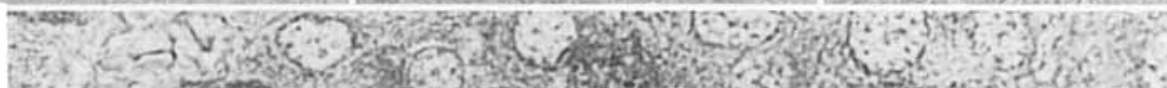

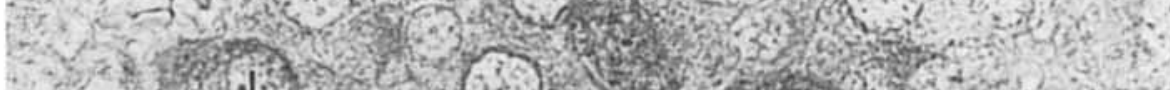

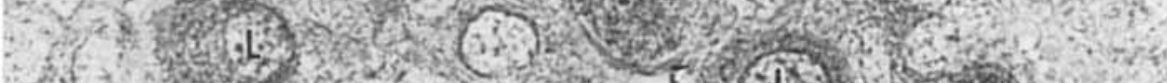

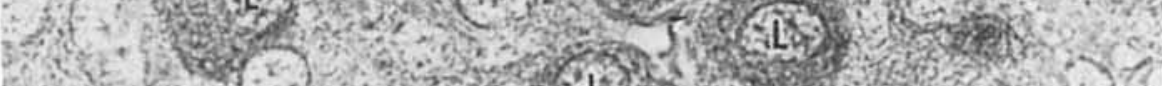
If 4 (2)

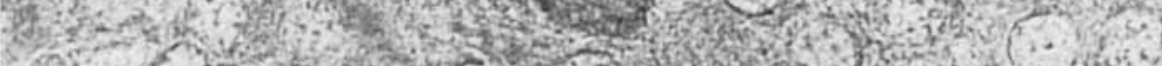
a.

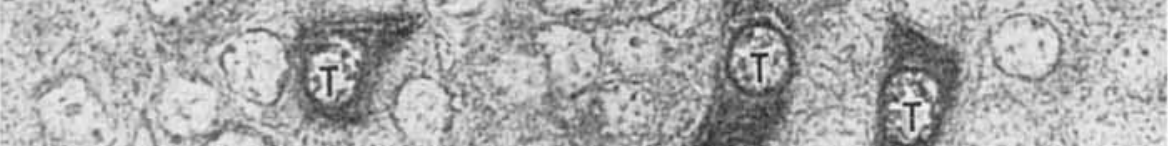

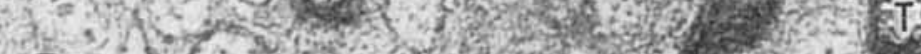

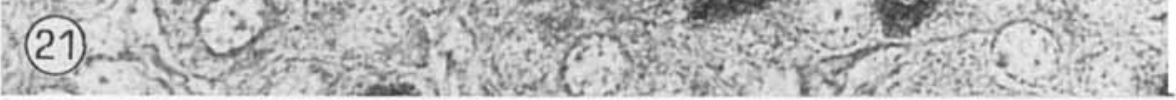

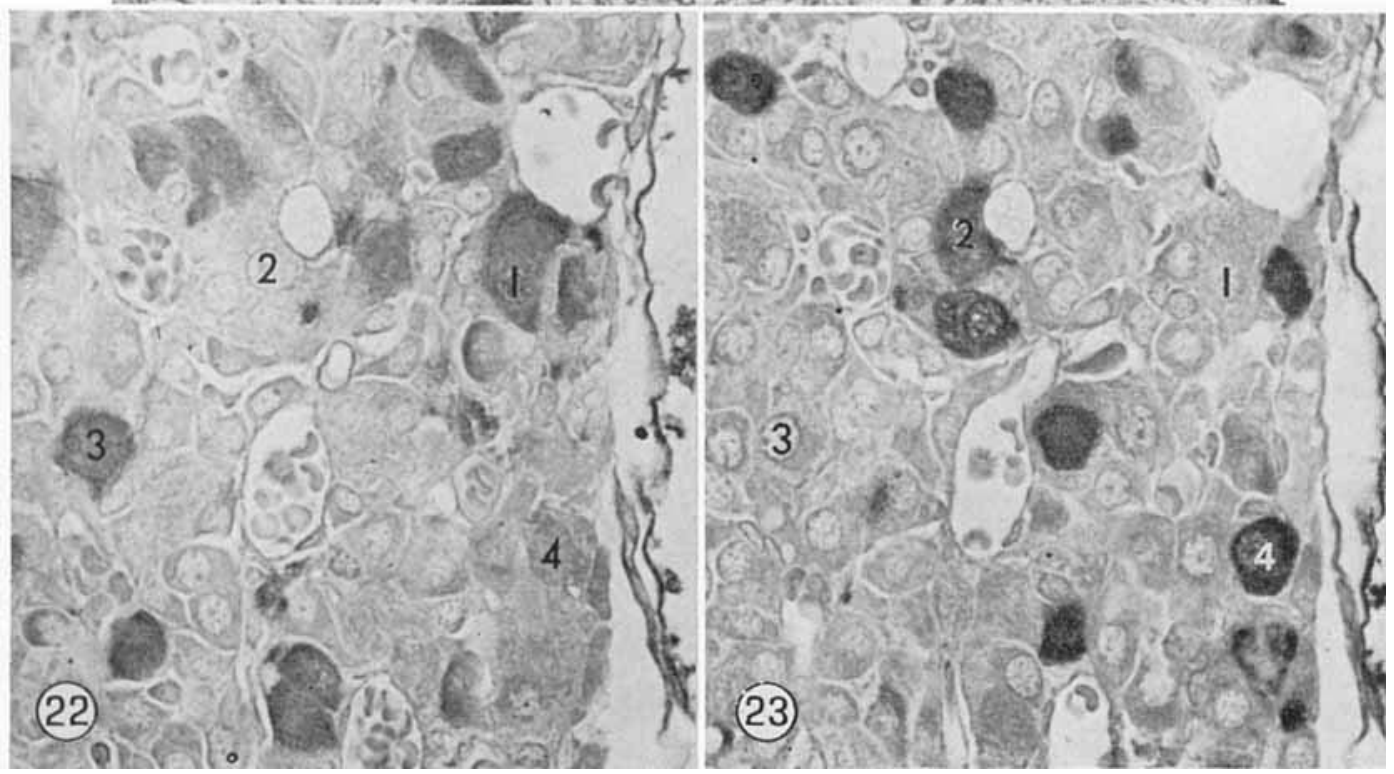

